\title{
The role of Pteridium arachnoideum (Kaulf) on the seed bank of the endangered Brazilian Cerrado
}

\author{
R. O. Xavier ${ }^{a}$, J. G. Alday ${ }^{b}$, R. H. Marrs ${ }^{b}$ and D. M. S. Matos ${ }^{a}$ \\ ${ }^{a}$ Departamento de Hidrobiologia, Universidade Federal de São Carlos - UFSCar, \\ Rodovia Washington Luis, Km 235, CP 676, CEP 13565-905, São Carlos, SP, Brazil \\ ${ }^{\mathrm{b} S}$ School of Environmental Sciences, Ecology and Marine Biology, University of Liverpool, \\ Liverpool, L69 3GP, UK \\ *e-mail: filosxavier@yahoo.com.br
}

Received: October 19, 2014 - Accepted: December 18, 2014 - Distributed: February 29, 2016

(With 3 figures)

\begin{abstract}
The native bracken (Pteridium arachnoideum) often occurs in mono-specific stands in the Brazilian Cerrado, and this dominance can impact on both the above-ground vegetation and soil seed bank. This study investigated how invasion by this species over a 20 -year period changed the seed bank and the relationship between the seed bank and litter mass. We extracted soil samples from three replicated invaded and uninvaded sites, and followed seedling emergence for six months. We collected the above-ground biomass and litter of $P$. arachnoideum in ten $1 \mathrm{~m}^{2}$ plots from three invaded sites. There was no difference between invaded and uninvaded areas in seed bank richness, diversity or overall abundance. The most abundant family was the Melastomataceae, followed by the Poaceae. The Melastomataceae was more abundant in uninvaded sites, but the most common species of this family (Tibouchinastenocarpa) was not affected. The grasses were more common in invaded sites in the rainy season and were affected by heterogeneity in the litter layer. The seed bank could play a role in the recovery of these invaded areas, but the presence of weeds and invasive grasses could constrain their use as a management strategy.
\end{abstract}

Keywords: bracken, Melastomataceae, litter, savanna, biological invasion.

\section{Impacto de Pteridium arachnoideum (Kaulf) no banco de sementes do Cerrado}

\section{Resumo}

O samambaião (Pteridium arachnoideum) frequentemente domina áreas de cerrado, e pode alterar tanto a vegetação estabelecida quanto o banco de sementes do solo. Nesse estudo investigamos como áreas de cerrado invadidas por essa espécie a mais de 20 anos alteraram o banco de sementes, e também a relação entre banco de sementes e quantidade de serapilheira. Extraímos amostras de solo em três invadidas e em áreas controle adjacentes, e monitoramos a emergência de plântulas por seis meses. Coletamos a biomassa aérea e a serapilheira de $P$. arachnoideum em dez parcelas de $1 \mathrm{~m}^{2}$ nas áreas invadidas. Ariqueza, diversidade e abundância totalnão diferiram entre áreas invadidas e controle. A família mais abundante foi Melastomataceae, seguida por Poaceae. Melastomataceae foi mais comum em áreas controle, mas não a espécie mais comum nessa família (Tibouchina stenocarpa). Gramíneas foram predominantes em áreas invadidas durante a estação chuvosa, e foram afetadas pela heterogeneidade da camada de serapilheira. O banco de sementes pode ser importante para a recuperação dessas áreas invadidas, mas esse uso pode ser prejudicado pela presença de ervas daninhas e gramíneas invasoras.

Palavras-chave: samambaião, Melastomataceae, serapilheira, savana, invasão biológica.

\section{Introduction}

Invasive species often form monospecific stands that impact on native plant communities (Pivello et al., 1999). These invasive species can outcompete established native species, reducing both their number and abundance, and altering the structure and function of the invaded communities (Marchante et al., 2011). As a consequence, the restoration potential of the ecosystem is affected, especially in areas where dispersal from nearby seed sources is limited (Funk et al., 2008). Also, many invasive species have also been shown to impact negatively on the soil seed bank (Pakeman and Hay, 1996; Gioria et al., 2012). Therefore, even after either a natural decline or 
deliberate weed control of invasive species, it is expected that at least some native species will have difficulties in re-establishing because of the reduced number of viable seeds in the soil (Wearne and Morgan, 2006). The worst case scenario is where there is a reduction in native species seeds/propagules and an increase in the invading species seeds/propagules in the soil seed bank (van der Valk and Pederson, 1989).

Invasive species can contribute to the impoverishment of seed banks in three ways: first, by decreasing the local seed rain by outcompeting established individuals of native species, thus fewer seeds of these species will be available to be incorporated (Gioria et al., 2014); second, by interfering with seed transfer to the soil by producing a very thick litter layer (Ghorbani et al., 2006), and third by increasing the number of its own propagules (Gioria et al., 2012). Consequently, we could expect an increasing impoverishment of the native soil seed bank where invasive species have colonized and persisted for a long time. The degree of impact, therefore, will depend on the abundance of the invasive species and on the length of time since invasion (Gioria et al., 2014). Relatively few studies have assessed the impacts of invasive species on the seed bank (Wearne and Morgan, 2006; Gioria and Osborne, 2010; Gioria et al., 2014), and especially in Neotropical regions (Silva and Silva Matos, 2006; Herrera and Nassar, 2009). Knowledge of the native species propagules and seeds remaining in the soil bank is an essential pre-requisite for the successful implementation of restoration programs in affected areas. Here, we investigate the effect of the invasion-dominance by the native fern species Pteridium arachnoideum(Kaulf) (Dennstaedtiaceae), hereafter called $P$. arachnoideum, on soil seed banks in Brazilian Cerrado.

Brazilian Cerrado, a shrub-covered savanna, is considered one of the 25 most endangered ecosystems in the world because of its high biodiversity and high level of destruction (Myers et al., 2000). In South America, it formerly covered about 2 million $\mathrm{Km}^{2}$, mostly in the Brazilian Central Plateau (Gottsberger and Silberbauer-Gottsberger, 2006), but in the last decades it has been reduced considerably. For example, in 1962 the total area of Cerrado in São Paulo state, Brazil covered about 33,929 Km² (13.7\%) (Borgonovi and Chiarini, 1965) but 30 years later in 1992, it was reduced to 2,379 $\mathrm{Km}^{2}(<1 \%)$ (Kronka et al., 1998). Given that continuous loss of Cerrado, any expansion of invasive species in its remnants will increase its degradation through continuing loss of biological diversity (Pivello et al., 1999; Miatto et al., 2011). One problematic invasive species of these areas is P.arachnoideum, which although being a native species, can be an aggressive weed species in some areas of Brazilian ecosystems (Pivello et al., 1999; Silva and Silva Matos, 2006).

In this study we tested two main hypotheses concerning the effects of $P$. arachnoideum on the Cerrado soil seed bank. First, that $P$. arachnoideum invasion reduces the size and composition of the soil seed bank compared to uninvaded sites. Second, that the deep litter layer produced by $P$. arachnoideum after invasion impacts negatively on the soil seed bank. A meta-analysis assessing the effect of invaded species on the soil seed bank found that invasion often produced a negative effect on the abundance and richness of native species, especially in invasions by large herbaceous species (Gioria et al., 2014). We, therefore, expect a negative effect of $P$. arachnoideum on the seed bank in the Cerrado sites, because monospecific stands of Pteridium species in both temperate and tropical regions showed lower seed bank diversity (Pakeman and Hay, 1996; Mitchell et al., 1998; Silva and Silva Matos, 2006). We also expect a negative relationship between litter biomass and seed bank abundance, considering that dense litter layer in Pteridium-dominated stands can be a barrier to seeds reaching the soil (Ghorbani et al., 2006).

\section{Methods}

We carried out this study in the Dr. Antônio T. Viana

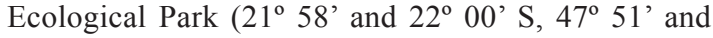
$47^{\circ} 52^{\prime}$ W; 72 ha) in São Carlos municipality, São Paulo state, Brazil. The climate has a rainy (October-March) and a dry season (April-September). The soils are latosols (Lorandi, 1985), and the vegetation is either gallery forest or Cerrado sensustricto, a typical savanna with a discontinuous canopy of shrub and tree species (Coutinho, 1978). According to local people, $P$. arachnoideum has been found in the park since its foundation in 1984, but its expansion into the study sites occurred after a fire in 1994. We compared the seed bank in three sites that had become dominated by $P$. arachnoideum over a 20-year period to those in three adjacent areas where $P$. arachnoideum was absent. Pteridium is a well-known weed worldwide, but most knowledge has been derived from studies in the northern hemisphere (Marrs and Watt, 2006). Pteridium may have a large underground rhizome network (Marrs and Watt, 2006) and achieve a high rate of vegetative growth (den Ouden 2000). These abilities enable the species to produce a dense frond canopy and deep litter layer, which prevents colonization by other plant species (Ghorbani et al., 2006; Silva and Silva Matos, 2006). These attributes provide Pteridium the ability to colonize and produce essentially mono-cultures. P. arachnoideum, causes similar problems in South America (Alonso-Amelot and Rodulfo-Baechler, 1996; Hartig and Beck, 2003; Silva and Silva Matos, 2006), suppressing understory species especially after fire (Silva-Matos et al., 2005).

We collected seed bank samples within each of the six sites (three invaded by $P$. arachnoideum and three uninvaded) in both the wet and the dry season to test for any seasonal differences. At each site, we located ten $1 \times 1 \mathrm{~m}$ plots randomly and collected a soil sample $(23 \mathrm{~cm}$ diameter, $5 \mathrm{~cm}$ depth). To investigate the relationship between biomass production and seed bank composition, we also sampled the above-ground biomass and litter layer during the wet season from the $1 \times 1 \mathrm{~m} 10$ plots within the three areas invaded by $P$. arachnoideum. The wet season was sampled because $P$. arachnoideum seems to have a larger biomass production during this period (Portela et al., 2009b). We harvested the biomass at ground level and separated 
into three fractions: biomass, litter of $P$. arachnoideum, and litter of other species. These fractions were dried at $80^{\circ} \mathrm{C}$ for $48 \mathrm{~h}$ and weighed.

We determined the size and composition of the soil seed bank by counting emergent seedlings under controlled conditions. This method is considered the most reliable for determining species composition of seed banks in plant communities (Roberts, 1981). We spread the soil samples into $21 \times 26 \mathrm{~cm}$ germination trays to a depth of $3.5 \mathrm{~cm}$ (Dalling et al., 1995), and covered them with crystal clear plastic to decrease airborne contamination and maintain humidity. Trays containing soils sterilized at $80{ }^{\circ} \mathrm{C}$ for $72 \mathrm{~h}$ were distributed randomly among the germination trays to assess airborne contamination. All trays remained in a greenhouse under natural conditions of air humidity and temperature for six months. They were kept moist, and the number of emergent seedlings recorded weekly. We promptly identified seedlings to species level, and when this was not possible, we transferred them to individual pots for subsequent identification.

We analyzed individual soil seed bank variables (total species abundance, richness, Simpson's diversity index, abundance of the four most abundant plant families, abundance of five of the most common native and exotic species) with generalized-linear-mixed-models (GLMM) using the 'glmmadmb' function in the ' $g$ lmmADMB' package (Fournier et al., 2012) implemented in the R Statistical Environment (v.3.1.0 R Development Core Team, 2014). We treated season (wet versus dry) and P. arachnoideum invasion/no invasion as fixed categorical factors, and plots nested within site and season as random factors with a random intercept to account for the spatial structure of the design (Pinheiro and Bates, 2000). We assumed a Gaussian error structure for species diversity and a negative binomial error structure for the rest of variables. There were a large number of zero data points for Melinis minutiflora (P. Beauv.) and $U$. decumbens Stapf, and accordingly a zero-inflated model was applied to these species (Zuur et al., 2009).

We assessed the relationship between the seed bank and the biomass and litter production in sites dominated by $P$. arachnoideum (rainy season only) using multiple linear regressions. Dependent variables were richness, overall abundance and abundance of the most common families and species in the seed bank, and independent variables included density, biomass, and litter (both $P$. arachnoideum and litter from other species). This more simple analysis was adopted because GLMM analyzes showed no significant random effect related to sites. We considered as best model those with lowest Bayesian Information Criterion (BIC) values. All models were performed and compared in the $\mathrm{R}$ Statistical Environment (R Development Core Team, 2014).

\section{Results}

A total of 2793 seedlings emerged during the experiment, 1531 from areas invaded by P. arachnoideum and 1262 from uninvaded areas. We identified about $71 \%$ of all seedlings to species level, $19 \%$ to genus level, $6 \%$ to family level and only $4 \%$ remained wholly unidentified. Seedlings belonged to 11 families and 56 species, with six species responsible for $73 \%$ of all individuals (Table 1). The most abundant family was the Melastomataceae, mainly represented by Tibouchina stenocarpa (DC.) Cogn. and Leandra aurea (Cham.) Cogn. (Table 1), followed by the Poaceae, mostly represented by the African species Melinis minutiflora P. Beauv. and Urochloa decumbens (Stapf.) R.D. Webster. Native species of the Rubiaceae and Asteraceae were common, but these were mainly small herbs and ruderal species (Table 1). All other families were less abundant and often represented by a single species (Table 1).

The GLMM models showed a significant interaction between seasonality and the presence of Pteridium arachnoideum in total seed abundance (Table 2a, Figure 1a). There was an increased abundance in control sites in the dry season compared to P.arachnoideum-invaded sites (Figure 1a, $\mathrm{p}<0.05$ ), whereas the differences in total seed abundance between invaded and uninvaded sites disappeared in the wet season (Figure 1a, $\mathrm{p}>0.05$ ). Surprisingly, GLMM models showed no significant effect of the presence of $P$. arachnoideum on seed bank richness and diversity (Figure 1a).

The abundance of Melastomataceae was significantly lower in the seed bank of invaded sites, although there was no season or invasion $x$ season interaction (Table $2 b$, Figure 2a). Within this family, however, Leandra aurea

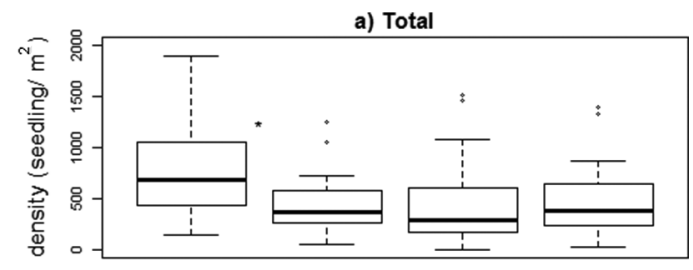

b) Richness
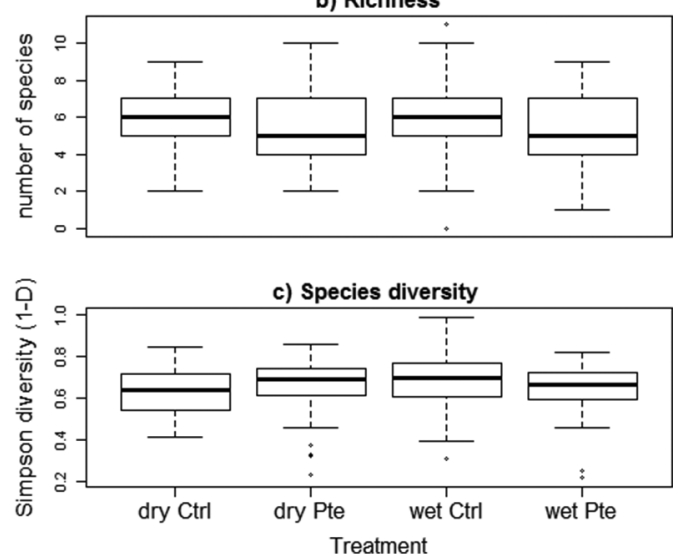

Figure 1. Boxplots of variables related to seed bank structure in sites of Cerrado invaded by Pteridium arachnoideum compared with reference uninvaded areas in two different seasons. (a) Total seed densities; (b) richness; (c) Simpson diversity (1-D). The output from generalized linear mixed-effects models (Table 1) is presented. Pte- invaded sites. Ctrl- control sites. Wet-rainy season. Dry- dry season. Asterisks $\left(^{*}\right)$ indicated significant differences between uninvaded and invaded sites in each season $\left({ }^{*} \mathrm{P}<0.05\right)$. 
Table 1. Species composition and seed abundance in the soil seed bank in the three sites invaded by Pteridiumaracnoideum $(\mathrm{P} 1, \mathrm{P} 2$ and $\mathrm{P} 3)$ and in the three uninvaded sites $(\mathrm{C} 1, \mathrm{C} 2$ and $\mathrm{C} 3)$ of Cerrado in the Southeast Brazil in both the rainy and dry season. Families and species within families are showed in decreasing order of total abundance in the soil seed bank. Species origin and status abbreviation: nat- native, rud-ruderal, ex-exotic, inv-invasive.

\begin{tabular}{|c|c|c|c|c|c|c|c|c|c|c|c|c|c|c|}
\hline \multirow{2}{*}{ Taxa } & \multirow{2}{*}{ Habit } & \multirow{2}{*}{$\begin{array}{l}\text { Origin/ } \\
\text { status }\end{array}$} & \multicolumn{6}{|c|}{ Rainy season } & \multicolumn{6}{|c|}{ Dry season } \\
\hline & & & $\mathrm{C1}$ & $\mathrm{C2}$ & C3 & P1 & $\mathbf{P 2}$ & $\overline{\text { P3 }}$ & $\overline{\mathrm{C1}}$ & $\mathrm{C2}$ & C3 & P1 & $\mathbf{P 2}$ & P3 \\
\hline \multicolumn{15}{|l|}{ Melastomataceae } \\
\hline Tibouchina stenocarpa & tree & nat & 24 & 43 & 19 & 4 & 58 & 46 & 1 & 8 & 108 & 2 & 44 & 176 \\
\hline Leandra aurea & shrub & nat & 20 & 54 & 16 & 7 & 19 & 9 & 45 & 81 & 16 & 38 & 33 & 9 \\
\hline Miconia albicans & shrub & nat & 9 & 0 & 3 & 3 & 1 & 0 & 15 & 3 & 0 & 3 & 0 & 2 \\
\hline Miconia rubiginosa & tree & nat & 7 & 0 & 1 & 0 & 1 & 0 & 0 & 0 & 1 & 1 & 0 & 0 \\
\hline Miconia ligustroides & tree & nat & 0 & 0 & 0 & 0 & 0 & 0 & 1 & 3 & 0 & 0 & 0 & 1 \\
\hline species 1 & & & 0 & 0 & 0 & 2 & 0 & 0 & 0 & 0 & 0 & 0 & 0 & 0 \\
\hline species 2 & & & 0 & 0 & 0 & 0 & 0 & 0 & 15 & 0 & 0 & 0 & 5 & 1 \\
\hline Undefined & & & 1 & 0 & 0 & 0 & 0 & 0 & 6 & 7 & 13 & 3 & 12 & 2 \\
\hline \multicolumn{15}{|l|}{ Poaceae } \\
\hline Urochloa decumbens & herb & exo/inv & 1 & 0 & 7 & 28 & 5 & 30 & 0 & 3 & 0 & 0 & 5 & 1 \\
\hline Melinis minutiflora & herb & exo/inv & 21 & 3 & 4 & 89 & 2 & 18 & 96 & 121 & 97 & 1 & 10 & 1 \\
\hline Panicum campestre & herb & nat & 1 & 0 & 1 & 0 & 2 & 0 & 0 & 6 & 17 & 0 & 0 & 13 \\
\hline Panicum sp. & herb & & 5 & 6 & 0 & 0 & 0 & 4 & 1 & 0 & 0 & 0 & 0 & 0 \\
\hline Paspalum pilosum & herb & nat & 0 & 0 & 1 & 0 & 0 & 0 & 0 & 1 & 0 & 0 & 0 & 0 \\
\hline Axonopus capillaris & herb & nat/ & 0 & 0 & 0 & 0 & 0 & 0 & 0 & 0 & 1 & 0 & 1 & 0 \\
\hline species 1 & herb & & 0 & 2 & 0 & 1 & 0 & 0 & 0 & 0 & 0 & 0 & 0 & 0 \\
\hline Eleusine indica & herb & nat/rud & 0 & 0 & 0 & 0 & 0 & 0 & 0 & 0 & 0 & 0 & 0 & 1 \\
\hline species 2 & herb & & 0 & 0 & 0 & 0 & 0 & 9 & 0 & 0 & 0 & 0 & 0 & 0 \\
\hline Undefined & & & 4 & 20 & 0 & 1 & 0 & 0 & 0 & 1 & 0 & 3 & 3 & 1 \\
\hline \multicolumn{15}{|l|}{ Asteraceae } \\
\hline Baccharis linearifolia & shrub & nat & 0 & 26 & 6 & 37 & 62 & 78 & 40 & 12 & 25 & 11 & 33 & 19 \\
\hline Mikania sp. & vine & & 10 & 4 & 5 & 11 & 4 & 11 & 3 & 2 & 8 & 8 & 17 & 4 \\
\hline Baccharis dracunculifolia & shrub & nat & 3 & 0 & 2 & 0 & 9 & 6 & 1 & 15 & 0 & 0 & 4 & 1 \\
\hline Chromolaena sp. & shrub & & 1 & 0 & 8 & 0 & 0 & 0 & 0 & 2 & 4 & 0 & 1 & 2 \\
\hline species 1 & & & 1 & 0 & 0 & 2 & 0 & 0 & 0 & 0 & 0 & 0 & 0 & 0 \\
\hline species 2 & & & 0 & 0 & 0 & 1 & 1 & 0 & 0 & 0 & 0 & 0 & 0 & 1 \\
\hline Pterocaulon alopecuroides & herb & nat/rud & 0 & 0 & 0 & 1 & 0 & 0 & 0 & 0 & 0 & 0 & 0 & 0 \\
\hline Rubiaceae & & & & & & & & & & & & & & \\
\hline Spermacoce sp. 1 & herb & & 76 & 3 & 1 & 1 & 17 & 9 & 57 & 6 & 0 & 5 & 5 & 16 \\
\hline Spermacace sp. 2 & herb & & 33 & 2 & 1 & 3 & 38 & 15 & 3 & 24 & 42 & 2 & 8 & 14 \\
\hline Coccocypselum lanceolatum & herb & nat & 0 & 0 & 0 & 0 & 0 & 0 & 2 & 0 & 0 & 0 & 1 & 0 \\
\hline \multicolumn{15}{|l|}{ Cyperaceae } \\
\hline Cyperus aggregatus & herb & nat/rud & 0 & 0 & 0 & 0 & 0 & 0 & 7 & 9 & 13 & 0 & 4 & 0 \\
\hline Fimbristylis spp. & herb & & 0 & 0 & 0 & 0 & 0 & 0 & 5 & 0 & 0 & 0 & 0 & 26 \\
\hline Cyperus surinamensis & herb & nat & 0 & 0 & 0 & 0 & 0 & 0 & 3 & 0 & 1 & 1 & 0 & 1 \\
\hline Undefined & & & 1 & 0 & 7 & 0 & 2 & 2 & 2 & 12 & 10 & 1 & 0 & 0 \\
\hline \multicolumn{15}{|l|}{ Fabaceae } \\
\hline species 1 & & & 0 & 0 & 0 & 0 & 0 & 0 & 0 & 5 & 0 & 0 & 0 & 0 \\
\hline Zornia latifolia & herb & nat & 0 & 0 & 0 & 0 & 0 & 0 & 0 & 2 & 0 & 0 & 0 & 0 \\
\hline Chamaecrista rotundifolia & herb & nat & 0 & 0 & 0 & 1 & 0 & 0 & 0 & 0 & 0 & 0 & 0 & 0 \\
\hline Senna chrysocarpa & herb & nat & 0 & 0 & 0 & 0 & 0 & 0 & 0 & 0 & 0 & 0 & 1 & 0 \\
\hline Undefined & & & 1 & 0 & 0 & 0 & 0 & 0 & 1 & 0 & 0 & 0 & 1 & 0 \\
\hline \multicolumn{15}{|l|}{ Lithraceae } \\
\hline Diplusodon virgatus & shrub & nat & 16 & 1 & 0 & 0 & 0 & 0 & 0 & 0 & 0 & 0 & 0 & 0 \\
\hline $\begin{array}{l}\text { Cucurbitaceae } \\
\text { species } 1\end{array}$ & vine & & 0 & 0 & 0 & 0 & 1 & 0 & 0 & 0 & 0 & 0 & 0 & 0 \\
\hline
\end{tabular}


Table 1. Continued...

\begin{tabular}{|c|c|c|c|c|c|c|c|c|c|c|c|c|c|c|}
\hline \multirow{2}{*}{ Taxa } & \multirow{2}{*}{ Habit } & \multirow{2}{*}{$\begin{array}{l}\text { Origin/ } \\
\text { status }\end{array}$} & \multicolumn{6}{|c|}{ Rainy season } & \multicolumn{6}{|c|}{ Dry season } \\
\hline & & & C1 & $\mathrm{C2}$ & C3 & P1 & $\mathbf{P 2}$ & P3 & C1 & $\mathrm{C2}$ & C3 & P1 & $\mathbf{P 2}$ & P3 \\
\hline Primulaceae & & & & & & & & & & & & & & \\
\hline $\begin{array}{l}\text { Rapanea umbellata } \\
\text { Rosaceae }\end{array}$ & tree & nat & 0 & 0 & 0 & 0 & 2 & 0 & 0 & 0 & 0 & 0 & 2 & 0 \\
\hline $\begin{array}{l}\text { Rubussp. } \\
\text { Euphorbiaceae }\end{array}$ & shrub & & 0 & 0 & 0 & 0 & 0 & 0 & 0 & 0 & 0 & 0 & 3 & 0 \\
\hline Maprounea guianensis & tree & nat & 0 & 0 & 0 & 0 & 0 & 0 & 0 & 0 & 0 & 2 & 0 & 0 \\
\hline Indeterminated & & & 5 & 54 & 2 & 3 & 0 & 0 & 1 & 2 & 2 & 18 & 16 & 4 \\
\hline
\end{tabular}

Table 2. Results of General Linear Mixed-Effects Models assessing the effects of Pteridium arachnoideuminvasion on soil seed bank composition in both the dry and rainy seasons in Cerrado sensustricto vegetation in Brazil, based in different dependent variables. (a) Total abundance, richness and species diversity; (b) Total abundance and of the five major plant families; (c) abundance of the most common exotic and native species. All models assumed a negative binomial distribution, except to species diversity, where we assumed a Gaussian distribution.

(a)

\begin{tabular}{|c|c|c|c|c|c|c|}
\hline Variables & Factor & Estimate & SE & $\mathbf{Z}$ & $\mathbf{P}$ & Significance \\
\hline \multirow{4}{*}{ Total abundance } & (Intercept) & 2.995 & 0.149 & 20.08 & $<0.001$ & $* * *$ \\
\hline & Pa.inv & 0.064 & 0.194 & 0.33 & 0.741 & ns \\
\hline & Dry.S & 0.502 & 0.218 & 2.30 & 0.021 & $*$ \\
\hline & Pa.inv x Dry.S & -0.626 & 0.269 & -2.33 & 0.020 & $*$ \\
\hline \multirow{4}{*}{ Richness } & (Intercept) & 1.778 & 0.113 & 15.77 & $<0.001$ & $* * *$ \\
\hline & Pa.inv & -0.089 & 0.112 & -0.79 & 0.430 & ns \\
\hline & Dry.S & -0.007 & 0.110 & -0.06 & 0.955 & ns \\
\hline & Pa.inv x Dry.S & -0.018 & 0.157 & -0.11 & 0.910 & ns \\
\hline \multirow{4}{*}{ Simpson 1-D } & (Intercept) & 0.677 & 0.031 & 21.79 & $<0.001$ & $* * *$ \\
\hline & Pa.inv & -0.078 & 0.041 & 1.88 & 0.063 & ns \\
\hline & Dry.S & -0.047 & 0.049 & -0.97 & 0.335 & ns \\
\hline & Pa.inv x Dry.S & 0.092 & 0.058 & 1.59 & 0.110 & ns \\
\hline
\end{tabular}

(b)

\begin{tabular}{|c|c|c|c|c|c|c|}
\hline \multirow[t]{4}{*}{ Melastomataceae } & (Intercept) & 1.957 & 0.229 & 8.55 & $<0.001$ & $* * *$ \\
\hline & Pa.inv & -0.722 & 0.272 & -2.65 & 0.008 & $* *$ \\
\hline & Dry.S & 0.393 & 0.249 & 1.58 & 0.110 & ns \\
\hline & Pa.inv x Dry.S & 0.575 & 0.355 & 1.62 & 0.105 & ns \\
\hline \multirow[t]{4}{*}{ Poaceae } & (Intercept) & 1.035 & 0.288 & 3.60 & $<0.001$ & $* * *$ \\
\hline & Pa.inv & 0.806 & 0.388 & 2.07 & 0.038 & ns \\
\hline & Dry.S & 1.405 & 0.385 & 3.65 & $<0.001$ & $* * *$ \\
\hline & Pa.inv x Dry.S & -2.957 & 0.551 & -5.36 & $<0.001$ & $* * *$ \\
\hline \multirow[t]{4}{*}{ Asteraceae } & (Intercept) & 0.856 & 0.263 & 3.26 & 0.001 & $* *$ \\
\hline & Pa.inv & 1.103 & 0.335 & 3.29 & 0.001 & $* *$ \\
\hline & Dry.S & 0.234 & 0.400 & 0.58 & 0.559 & ns \\
\hline & Pa.inv x Dry.S & -1.212 & 0.494 & -2.45 & 0.014 & $*$ \\
\hline \multirow[t]{4}{*}{ Rubiaceae } & (Intercept) & 1.594 & 0.572 & 2.78 & 0.005 & $* *$ \\
\hline & Pa.inv & -0.480 & 0.483 & -0.99 & 0.321 & ns \\
\hline & Dry.S & -0.102 & 0.632 & -0.16 & 0.871 & ns \\
\hline & Pa.inv x Dry.S & -0.447 & 0.710 & -0.63 & 0.529 & ns \\
\hline
\end{tabular}

+Denotes zero-inflated models were fitted. Significance: $\mathrm{ns}=\mathrm{P}>0.05{ }^{*}=\mathrm{P}<0.05 .^{* *}=\mathrm{P}<0.01 .^{* * *}=\mathrm{P}<0.001$. The intercept is vegetation with no $P$. arachnoideum invasion in the wet season; $\mathrm{Pa} . \mathrm{inv}=P$. arachnoideum invasion and Dry.S $=$ dry season. 
Table 2. Continued...

(c)

\begin{tabular}{|c|c|c|c|c|c|c|c|}
\hline Origin & Variable & Factor & Estimate & SE & $\mathbf{z}$ & $\mathbf{P}$ & Significance \\
\hline \multirow{8}{*}{ Exotic } & \multirow{4}{*}{$\begin{array}{l}\text { +Melinis } \\
\text { minutiflora }\end{array}$} & (Intercept) & -0.058 & 0.438 & -0.13 & 0.895 & ns \\
\hline & & Pa.inv & 1.230 & 0.512 & 2.40 & 0.016 & $*$ \\
\hline & & Dry.S & 2.446 & 0.537 & 4.55 & $<0.001$ & $* * *$ \\
\hline & & Pa.inv x Dry.S & -4.518 & 0.749 & -6.03 & $<0.001$ & $* * *$ \\
\hline & \multirow{4}{*}{$\begin{array}{l}+ \text { Urochloa } \\
\text { decumbens }\end{array}$} & (Intercept) & -1.216 & 0.506 & -2.40 & 0.016 & $*$ \\
\hline & & Pa.inv & 1.958 & 0.625 & 3.13 & 0.002 & $* *$ \\
\hline & & Dry.S & -1.086 & 0.841 & -1.29 & 0.197 & ns \\
\hline & & Pa.inv x Dry.S & -1.265 & 1.062 & -1.19 & 0.233 & ns \\
\hline \multirow{12}{*}{ Native } & \multirow{4}{*}{$\begin{array}{c}\text { Baccaris } \\
\text { linearifolia }\end{array}$} & (Intercept) & 0.170 & 0.413 & 0.41 & 0.680 & ns \\
\hline & & Pa.inv & 1.605 & 0.549 & 2.93 & 0.003 & $* *$ \\
\hline & & Dry.S & 0.773 & 0.555 & 1.39 & 0.164 & $\mathrm{~ns}$ \\
\hline & & Pa.inv x Dry.S & -1.957 & 0.762 & -2.37 & 0.018 & $*$ \\
\hline & \multirow{4}{*}{ Leandra aurea } & (Intercept) & 1.080 & 0.357 & 3.03 & 0.002 & $* *$ \\
\hline & & Pa.inv & -1.168 & 0.351 & -3.33 & $<0.001$ & $* * *$ \\
\hline & & Dry.S & 0.274 & 0.325 & 0.84 & 0.398 & ns \\
\hline & & Pa.inv x Dry.S & 0.611 & 0.464 & 1.31 & 0.188 & ns \\
\hline & \multirow{4}{*}{$\begin{array}{l}\text { Tibouchina } \\
\text { stenocarpa }\end{array}$} & (Intercept) & 1.063 & 0.346 & 3,07 & 0.002 & $* *$ \\
\hline & & Pa.inv & -0.611 & 0.413 & -1.48 & 0.139 & ns \\
\hline & & Dry.S & -1.372 & 1.012 & -1.36 & 0.175 & $\mathrm{~ns}$ \\
\hline & & Pa.inv x Dry.S & 1.523 & 0.593 & 2.57 & 0.010 & $*$ \\
\hline
\end{tabular}

+ Denotes zero-inflated models were fitted. Significance: $\mathrm{ns}=\mathrm{P}>0.05{ }^{*}=\mathrm{P}<0.05 .{ }^{* *}=\mathrm{P}<0.01 .{ }^{* * *}=\mathrm{P}<0.001$. The intercept is vegetation with no $P$. arachnoideum invasion in the wet season; Pa.inv $=$ P. arachnoideum invasion and Dry.S $=$ dry season.

showed a lower abundance in invaded sites (Table 2c, Figure 3d). The seed bank abundance of the Asteraceae and Poaceae, as well as the most common species of these families, showed a significant interaction between invasion and season (Table 2b). The abundance of Poaceae and $M$. minutiflora, which represented most of the individuals in this family, was greater in the invaded sites in the rainy season, but lower in these same sites in the dry season (Table 2b,c, Figure 2b, Figure 3b). Urochloa decumbens was always more abundant than the controls in the invaded sites (Table 2c, Figure 3e). On the other hand, Asteraceae and Baccharis linearifolia, the most abundant species in this family, showed a significant invasion $\times$ season interaction (Tables $2 \mathrm{~b}$ and c, Figure 2c, Figure 3c). Both were significantly more abundant in invaded sites in the rainy season, whereas this difference disappeared in the dry season. Finally, there were no significant effects of $P$. arachnoideum-invasion and season on the abundance of the Rubiaceae (Table 2b, Figure 2d).

The linear model with the lowest BIC values to the relationship between seed bank and biomass/litter production included only the amount of litter produced by $P$. arachnoideum and other species litter as independent variables (Table 3). The abundance of Poaceae and M minutiflora were significantly negatively related to the amount of litter produced by P. arachnoideum (Table 3). Conversely, the amount of litter produced by other species had a positive effect on the seed bank abundance of Poaceae, total abundance, Asteraceae, Rubiaceae, M. minutiflora and $U$. decumbens (Table 3 ). On the contrary, the models for the total abundance $(\mathrm{P}=0.033)$, the Asteraceae $(\mathrm{P}=0.049)$ and the Rubiaceae $(\mathrm{P}=0.038)$ were only marginally significant (Table 3).

\section{Discussion}

Our results suggest that abundance, richness and species diversity of the soil seed bank in sites dominated by $P$. arachnoideum was similar to uninvaded sites. The absence of a negative effect of invasive species in the seed bank richness is common in the literature, but most of these studies found, at least, a lower abundance of native species in invaded sites (Gioria et al., 2014). We believe that this might be related either to the dominance of a few species with more persistent seed banks in both invaded and uninvaded sites or to the relatively short time since the invasion. Nevertheless, here the invasion occurred over 20 years, whereas stands in the northern hemisphere, where P. aquilinum(L.) Kuhn also has impacted on seed banks, have been colonized for centuries (Ghorbani et al., 2007). Negative effects of P.arachnoideum on the seed bank of Cerrado sites were limited to the Melastomataceae, of which only one, relatively less common native species (L. aurea) showed an individual significant reduction. This result contrasts previous studies, which found a lower abundance or richness of native species in Pteridium stands (Pakeman and Hay, 1996; Mitchell et al., 1998; Silva and Silva Matos, 2006).

It seems that our results were also affected by the low richness of woody species in the seed bank of both invaded 

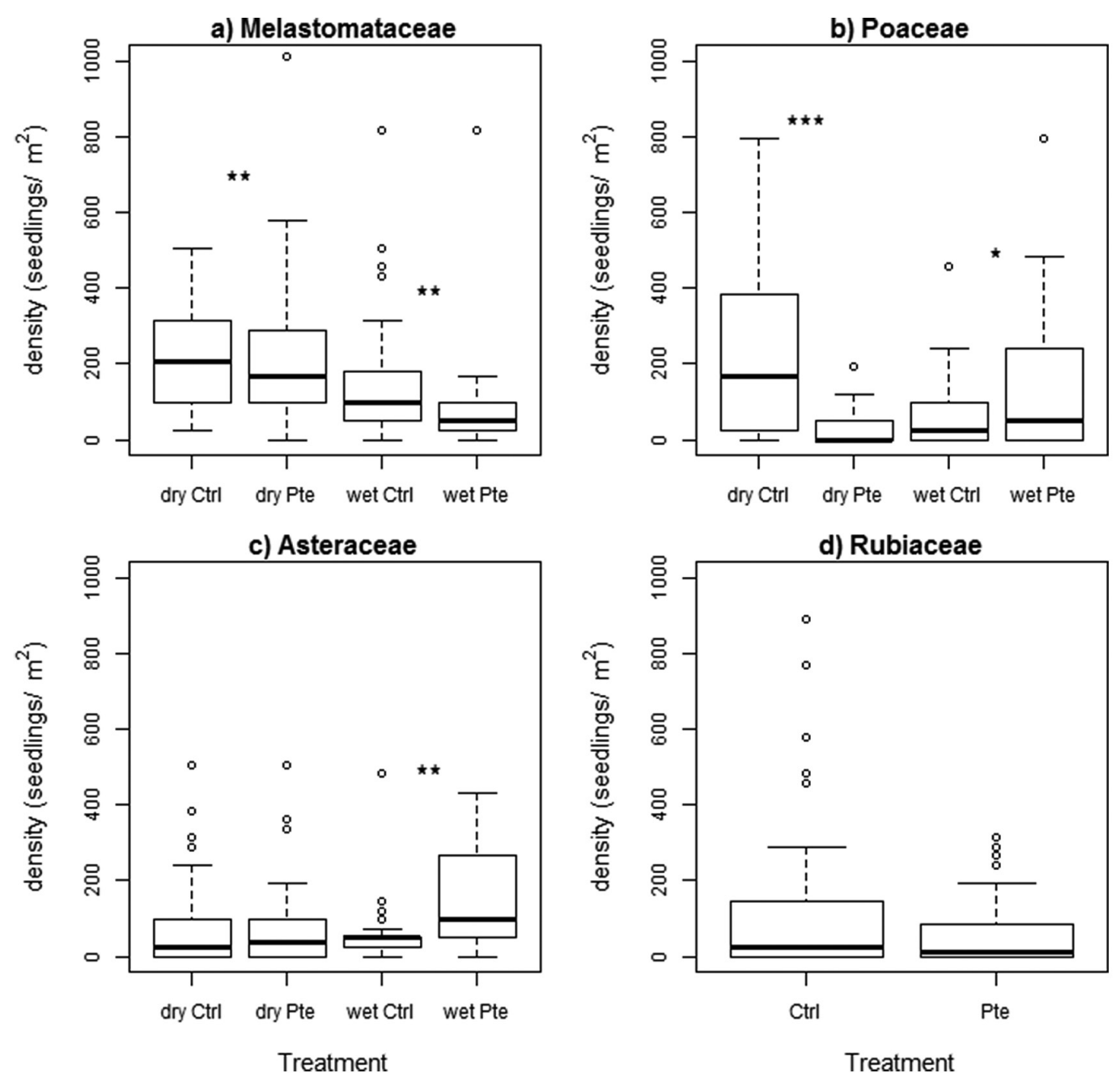

Figure 2. Density of the five commonest families in the seed bank of sites of Cerrado invaded by Pteridium arachnoideum, compared to uninvaded adjacent sites. Data are showed both to the rainy and dry season. (a) Melastomataceae. (b) Poaceae. (c) Asteraceae. (d) Rubiaceae. The output from generalized linear mixed-effects models runned to each family (Table 1) is presented. Pte- invaded sites. Ctrl- control sites. Wet-rainy season. Dry- dry season. Significance to a the comparison between uninvaded and invaded sites in each season, or between invaded and uninvaded sites when the interaction between season and invasion was not significant: $* \mathrm{P}<0.05, * * \mathrm{P}<0.01, * * * \mathrm{P}<0.001$.

Table 3. Best linear models of the relationship between seed bank structure and biomass production related variables in Cerrado sites invaded by Pteridium arachnoideum in the southeast of Brazil. Dependent variables are the overall abundance and richness of the seed bank, as well as the abundance of the most common families and exotic species, and independent variables are the litter biomass from $P$. arachnoideum e other species.

\begin{tabular}{|c|c|c|c|c|c|c|c|c|c|c|}
\hline \multirow{2}{*}{$\begin{array}{c}\text { Model components } \\
\text { Variables }\end{array}$} & \multicolumn{3}{|c|}{ intercept } & \multicolumn{3}{|c|}{ P. arachnoideum litter } & \multicolumn{3}{|c|}{ other species litter } & \multirow{2}{*}{$\mathbf{r}^{2} \mathbf{a d j}$} \\
\hline & SE & $\mathbf{t}$ & p & SE & $\mathbf{t}$ & p & SE & $t$ & p & \\
\hline Total abundance & 12.72 & 1.39 & 0.177 & 0.02 & 0.51 & 0.615 & 0.05 & 2.25 & $0.033^{*}$ & 0.11 \\
\hline Melastomataceae & 8.10 & 0.26 & 0.798 & 0.01 & 0.82 & 0.418 & 0.03 & 0.48 & 0.636 & 0.04 \\
\hline Poaceae & 4.29 & 2.23 & $0.035^{*}$ & 0.01 & 2.48 & $0.020 * * *$ & 0.02 & 3.79 & $<0.001 * * *$ & 0.41 \\
\hline Asteraceae & 6.53 & 0.90 & 0.377 & 0.01 & 0.55 & 0.590 & 0.03 & 2.06 & $0.049 *$ & 0.09 \\
\hline Rubiaceae & 2.46 & 1.00 & 0.328 & 0.00 & 1.05 & 0.305 & 0.01 & 2.18 & $0.038 *$ & 0.13 \\
\hline M. minutiflora & 3.23 & 2.04 & 0.051 & 0.00 & 2.37 & $0.026^{*}$ & 0.01 & 3.08 & $0.005 * *$ & 0.33 \\
\hline U. decumbens & 2.19 & 0.63 & 0.536 & 0.00 & 1.02 & 0.318 & 0.01 & 3.33 & $0.003 * *$ & 0.28 \\
\hline Richness & 1.57 & 3.60 & $0.001 * * *$ & 0.00 & 0.05 & 0.964 & 0.01 & 0.24 & 0.810 & 0.07 \\
\hline
\end{tabular}

Significance: ${ }^{*} \mathrm{p}<0.05 .{ }^{* *} \mathrm{p}<0.01 . * * * \mathrm{p}<0.001$. 
a) Tibouchina stenocarpa

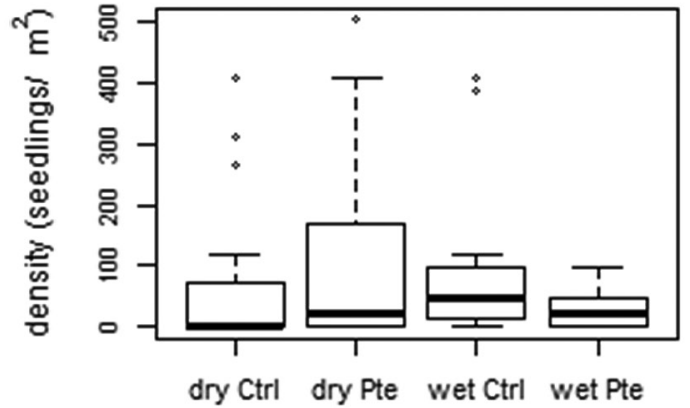

c) Baccharis linearifolia

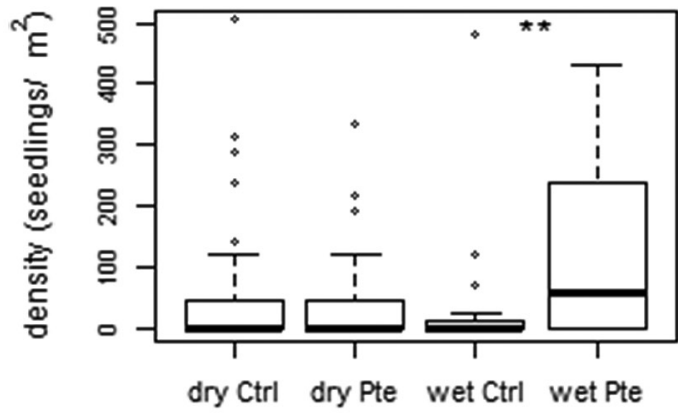

e) Urochloa decumbens

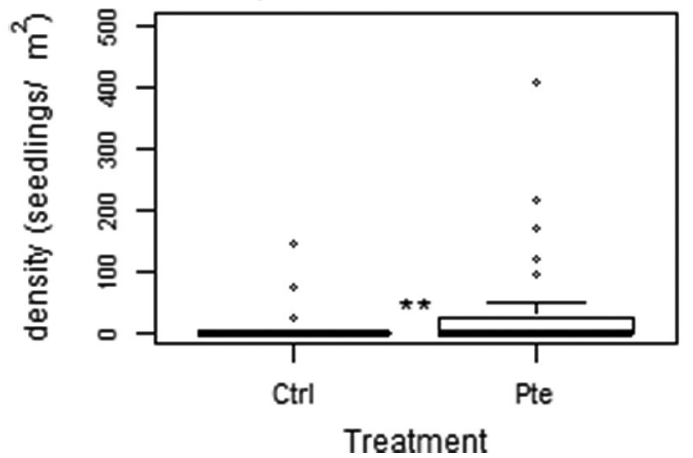

b) Melinis minutiflora

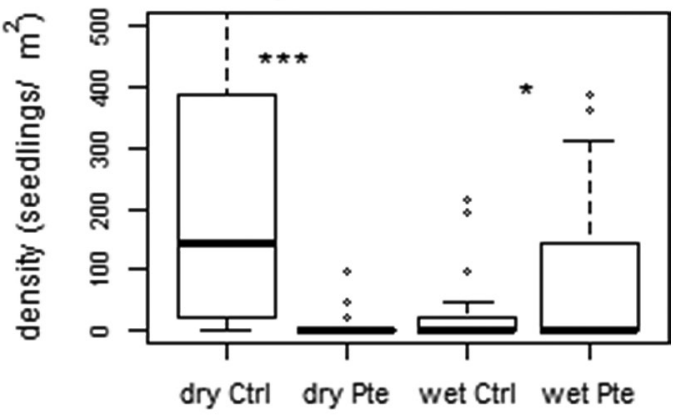

d) Leandra aurea

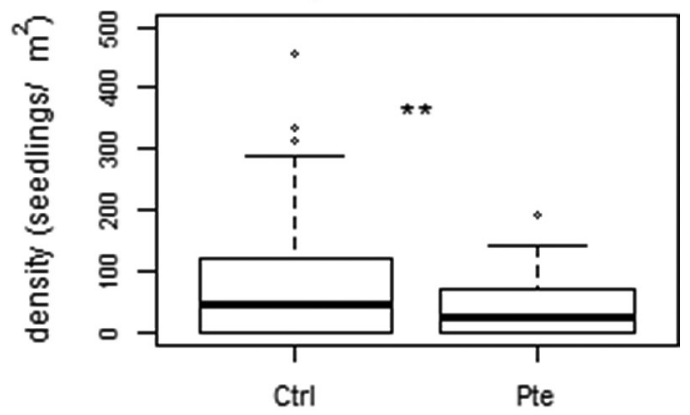

Treatment

Figure 3. Density of the most common exotic (a-b) and native species (c-e) in the seed bank of sites of Cerrado invaded by Pteridium arachnoideum, compared to uninvaded adjacent sites in two different seasons. Output from generalized linear mixed-effects models performed to each species (Table 1) is presented. Pte- invaded sites. Ctrl- control sites. Wet-rainy season. Dry- dry season. Significance of a comparison between uninvaded and invaded sites in each season, or between invaded and uninvaded sites when the interaction between season and invasion was not significant: $* \mathrm{P}<0.05, * * \mathrm{P}<0.01$, $* * * \mathrm{P}<0.001$.

and control sites. Both invaded and uninvaded sites had a lower number of woody species than would be expected considering the local woody flora described previously in the study area by Miatto et al. (2011). Miatto et al. detected 33 woody species in the same invaded sites and 64 in the adjacent uninvaded sites, which in general were also more diverse. Here, we only found five tree species in the seed bank of the same sites (invaded five species, versus uninvaded three species), but a single very abundant species (T. stenocarpa) was the responsible for most occurrences. These large dissimilarities between the composition of the seed bank and the established vegetation often occur because the maintenance of a large seed bank is just one of many regenerative strategies adopted by tropical species (Thompson and Grime, 1979; Simpson, 1989; Grime, 2001). Many of the tree species, like many tropical species, produce recalcitrant seeds, and hence they do not produce a persistent seed bank (Vazquez-Yanes and Orozco-Segovia, 1993). However, we believe the high disparity found in here may is related to intrinsic characteristics of the Cerrado vegetation, where several species reproduces either vegetatively through a 
bud bank or the germination of recently-dispersed seeds, usually after disturbance (Hoffmann, 1998). Consequently, remarkable differences between invaded and uninvaded sites concerned with the established woody vegetation (Miatto et al., 2011) could not be found in the seed bank.

The seed morphology of the dominant species in the seed bank of both invaded and uninvaded sites highlights the prevalence of persistent seed banks in high biomass sites dominated by Pteridium. Studies on Pteridium aquilinum stands on British heathlands found that its seed bank is often dominated by Calluna vulgaris (L.) Hull (Ericaceae), a native shrub that produces large amounts of small seeds (Pakeman and Hay, 1996). In the Atlantic Forest, Silva and Silva Matos (2006) observed that Tibouchina sp. (Melastomataceae) was the second commonest genus in the seed bank of P.arachnoideum-dominated areas. Like C. vulgaris, seeds of Tibouchina, including T. stenocarpa, the most common species found in their study, are small and abundantly produced (Barroso et al., 1999; Pinheiro and Ribeiro, 2001). A review of temperate communities found a negative association between seed size and persistence in the seed bank (Thompson et al., 1998). Dormancy mechanisms were reported for Tibouchina genus (Silveira et al., 2012), and could also have contributed to the presence of $T$. stenocarpa even in sites with a poor seed rain and subject to a long-term presence of $P$. arachnoideum. In Furthermore, we believe that the dominance of these small seeds in invaded sites may be intensified by the dense above-ground biomass and deep litter layer observed in Pteridium stands, which could be an effective barrier to incorporate larger seeds into the soil seed bank (Ghorbani et al., 2006). This could also explain the lower abundance of $L$. aurea in sites with $P$. arachnoideum, as that his species produces fleshy fruits and relatively large seeds which zoocoric dispersion (Manhães, 2003).

Although species with small seeds and persistent seed bank are dominant in the invaded sites, exotic grasses and ruderal native species seem to maintain transient seed banks in sites dominated by P. arachnoideum. Our results showed that M. minutiflora and B. linearifolia were more common in the seed bank of invaded sites in the rainy season, whereas in the dry season the former was more abundant in control sites and the latter had similar abundance regardless of the invasion by $P$. arachnoideum. A similar tendency occurred to $U$. decumbens, although it was more common in invaded sites also in the dry season. Such variability is recurrent in the soil seed bank and is affected by differences in the timing and scales of propagule dispersion, longevity in the soil and incorporation into the seed bank (Thompson and Grime, 1979; Simpson, 1989). Since this heterogeneity on the seed bank occurs in species with transient seed banks (Thompson and Grime, 1979), it seems that M. minutiflora and $B$. linearifolia have a less persistent seed bank compared to species from Melastomataceae family.

Although $P$. arachnoideum achieve a high performance in our study sites, high within-site heterogeneity may also have contributed to the absence of a clear negative effect of $P$. arachnoideum even over species with transient seed banks. The mean frond biomass of $P$. arachnoideum $\left(958 \pm 370 \mathrm{~g} / \mathrm{m}^{2}\right)$ found here is greater than found in most P.aquilinum stands (Marrs and Watt, 2006). Also, it is greater than that obtained for $P$. arachnoideum in both high-altitude areas in Venezuela $\left(287 \pm 22.4 \mathrm{~g} / \mathrm{m}^{2}\right.$ ) (Alonso-Amelot and Rodulfo-Baechler, 1996), and in the Atlantic Rain Forest $\left(236 \mathrm{~g} / \mathrm{m}^{2}\right)$ (Portela et al., 2009a). Conversely, the mean litter biomass $\left(1012 \pm 285 \mathrm{~g} / \mathrm{m}^{2}\right)$ was low compared to that obtained by Bray (1991) to P. esculetum (G. Forst.) Cockayne $\left(3364 \mathrm{~g} / \mathrm{m}^{2}\right)$, but is larger than found in the Atlantic Rain Forest to $P$. arachnoideum $\left(751 \mathrm{~g} / \mathrm{m}^{2}\right)$ (Portela et al., 2009a). An increased overall above-ground biomass $\backslash$ litter has been considered to have negative effects on local seed rain in invaded sites, and therefore, an impact on soil seed banks (Gioria et al., 2012). However, it is expected that some local heterogeneity in the level of invasion, mostly because suitability of local abiotic conditions and time since the invasion would be highly variable. This high within-site variation in above-ground and litter biomass in our sites is likely a result of the relatively young age of the stands (20 years). Alongside the low richness and the expected high spatial heterogeneity in the seed bank, this heterogeneity may have decreased the overall effect of $P$. arachnoideum on the seed bank related to control sites (Thompson and Grime, 1979).

The importance of spatial heterogeneity inside Pteridium stands for transient seed banks is highlighted by the relationship between the presence of African grasses and the litter accumulation. The abundance of $M$. minutiflora in the soil seed bank decreased as the amount of $P$. arachnoideum litter increased, but increased linearly with other species litter. We believe that these responses relate to the short-term longevity $M$. minutiflora seeds in the soil. Seed bank presence depends on effective seed rain and successful seed incorporation into the soil (Thompson and Grime, 1979). Thus, it is hypothesized for this species that incorporation was less effective under the larger amount of litter produced by $P$. arachnoideum, acting as a barrier to seed arrival into the soil (Ghorbani et al., 2006). On the other hand, the presence of litter from other species was a direct consequence of the presence of other species, which may have created microsites with lower litter accumulation e allowed higher rates of seed incorporation into the soil (Ghorbani et al., 2006). This could explain why the relationship between seed bank and litter was highly significant for African grasses (M. minutiflora and $U$. decumbens) which have a short-term seed bank, weakly significant for ruderals from the Asteraceae and Rubiaceae with a more constant seed bank, and absent for the Melastomataceae with a persistent seed bank.

Our results suggest that transient seed banks are more likely to occur in microsites where P.arachnoideum-dominance is less pronounced. However, in our study sites these species are weeds and invasive grasses, whose regeneration could impair restoration of native species from the seed bank pool. Pioneer species, e.g. the Melastomataceae, are commonly found both in the seed bank and in the initial process of natural succession (Baider et al., 2001; Grime, 
2001; Silva and Silva Matos, 2006). Consequently, the presence of T. stenocarpa in the seed bank, even in stands dominated by $P$. arachnoideum, could be important for the restoration of these sites. However, the occurrence of fire and climatic seasonality can limit the establishment of plants from seeds in Cerrado (Hoffmann, 1998; Gottsberger and Silberbauer-Gottsberger, 2006), so that an effective vegetation restoration strategy reliant on seed banks would depend on a large amount of native seeds in the soil. Unfortunately, the remaining dominant native species in the $P$. arachnoideum - invaded areas were short-lived perennials from the Asteraceae and Rubiaceae families, whose seed banks may have a little role in the restoration of these sites. Similarly, the presence of exotic species as $U$. decumbens and M. minutiflora in the seed bank of invaded sites may be considered a negative effect of $P$. arachnoideum. The dominance of these undesirable species in the seed bank is a common consequence of long-term invasions (Gioria et al., 2012, 2014), and thus occur in other sites invaded by Pteridium (Marrs and Watt, 2006; Silva and Silva Matos, 2006). The presence of $U$. decumbens and M. minutiflora both in the established vegetation and seed bank is an important constraint for seed regeneration of native species, given that both are highly invasive species in the Cerrado (Pivello et al., 1999; Barbosa et al., 2008; Hoffmann and Haridasan, 2008). Both species are superior competitors to native grasses, achieve high growth rates under favorable conditions and often spread after fire (Williams and Baruch, 2000), especially U. decumbens (Pivello et al., 1999). These abilities could favor these species in P. arachnoideum-invaded sites, with are especially subject to fire because of the large amount of dry biomass (Silva Matos and Santos, 2002), or in invaded sites managed by mechanical removal (Marrs and Watt, 2006).

Our results did not support the hypothesis of an impoverished soil seed bank in sites invaded by $P$. arachnoideum over a period of 20 years. However, both life-history aspects and the high litter production of $P$. arachnoideum may constrain the soil seed bank richness and abundance in the future. The negative association between seed bank abundance and litter layer indicates that heterogeneity of the dominance of $P$. arachnoideum may give an opportunity to the development of a seed bank with more transient species. However, in our study sites these species are native weeds and African invasive grasses. The accumulation of these undesirable species might limit a seed bank centered restoration in Cerrado sites dominated by P. arachnoideum. This is an addition threat to this vegetation type, which in the southeast of Brazil is already highly fragmented and threatened from development and changed fire regimes (Durigan et al., 2007).

\section{Acknowledgements}

We thank the Brazilian Government for the financial support from the CNPq/PIBIC program, and P. Dodonov for the support in statistical analysis, fieldwork, and experimental monitoring.

\section{References}

ALONSO-AMELOT, M.E. and RODULFO-BAECHLER, S., 1996. Comparative spatial distribution, size, biomass and growth rate of two varieties of bracken fern (Pteridium aquilinum L. Kuhn) in a neotropical montane habitat. Plant Ecology, vol. 125, no. 2, pp. 137-147. http://dx.doi.org/10.1007/BF00044647.

BAIDER, C., TABARELLI, M. and MANTOVANI, W., 2001. The soil seed bank during Atlantic Florest regeneration in southeast Brazil. Brazilian Journal of Biology $=$ Revista Brasileira de Biologia, vol. 61, no. 1, pp. 35-44. http://dx.doi.org/10.1590/ S0034-71082001000100006. PMid:11340460.

BARBOSA, E.G., PIVELLO, V.R. and MEIRELLES, S.T., 2008. Allelopathic evidence in Brachiaria decumbens and its potential to invade the Brazilian cerrados. Brazilian Archives of Biology and Technology, vol. 51, no. 4, pp. 825-831. http://dx.doi.org/10.1590/ S1516-89132008000400021.

BARROSO, C.M., MORIM, M.P., PEIXOTO, A.L. and ICHASO, C.L.F., 1999. Frutos e sementes:morfologia aplicada á sistemática de dicotiledôneas. Viçosa: Universidade Federal de Viçosa.

BORGONOVI, M. and CHIARINI. J.V., 1965. Cobertura vegetal do estado de São Paulo: I. Levantamento por fotointerpretão das áreas cobertas com cerrado, cerradão e campo, em 1962. Bragantia, vol. 24, pp. 159-172. http://dx.doi.org/10.1590/ S0006-87051965000100014.

BRAY, J.R., 1991. Growth, biomass, and productivity of a bracken (Pteridium esculentum) infested pasture in Marlborough Sounds, New Zealand. New Zealand Journal of Botany, vol. 29, no. 2, pp. 169-176. http://dx.doi.org/10.1080/0028825X.1991.10416719.

COUTINHO, L.M., 1978. O conceito de cerrado. Revista Brasileira de Botanica $=$ Brazilian Journal of Botany, vol. 1, no. 1, pp. 17-23.

DALLING, J.W., SWAINE, M.D. and GARWOOD, N.C., 1995. Effect of soil depth on seedlingemergence in tropical soil seed bank investigations. Functional Ecology, vol. 9, no. 1, pp. 119121. http://dx.doi.org/10.2307/2390098.

DEN OUDEN, J., 2000. The role of Bracken (Pteridium aquillinum) in forest dynamics. Wageningen: Wageningen University.

DURIGAN, G., SIQUEIRA, M.F.D. and FRANCO, G.A.D.C., 2007. Threats to the cerrado remnants of the state of São Paulo, Brazil. Scientia Agricola, vol. 64, no. 4, pp. 355-363. http://dx.doi. org/10.1590/S0103-90162007000400006.

FOURNIER, D., SKAUG, H., ANCHETA, J., IANELLI, J., MAGNUSSON, A., MAUNDER, M., NIELSEN, A. and SIBERT, J., 2012. AD Model Builder: using automatic differentiation for statistical inference of highly parameterized complex nonlinear models. Optimization Methods \& Software, vol. 27, no. 2, pp. 233-249. http://dx.doi.org/10.1080/10556788.2011.597854.

FUNK, J.L., CLELAND, E.E., SUDING, K.N. and ZAVALETA, E.S., 2008. Restoration through reassembly: plant traits and invasion resistance. Trends in Ecology \& Evolution, vol. 23, no. 12, pp. 695-703. http://dx.doi.org/10.1016/j.tree.2008.07.013. PMid:18951652.

GHORBANI, J., LE DUC, M.G., MCALLISTER, H.A., PAKEMAN, R.J. and MARRS, R.H., 2006. Effects of the litter layer of Pteridium aquilinum on seed banks under experimental restoration. Applied Vegetation Science, vol. 9, no. 1, pp. 127136. http://dx.doi.org/10.1658/1402-2001(2006)9[127:EOTL LO]2.0.CO;2. 
GHORBANI, J., LE DUC, M.G., MCALLISTER, H.A., PAKEMAN, R.J. and MARRS, R.H., 2007. Effects of experimental restoration on the diaspore bank of an upland moor degraded by Pteridium aquilinum invasion. Land Degradation \& Development, vol. 18, no. 6, pp. 659-669. http://dx.doi.org/10.1002/ldr.804.

GIORIA, M. and OSBORNE, B., 2010. Similarities in the impact of three large invasive plant species on soil seed bank communities. Biological Invasions, vol. 12, no. 6, pp. 1671-1683. http://dx.doi. org/10.1007/s10530-009-9580-7.

GIORIA, M., PYSEK, P. and MORAVCOVA, L., 2012. Soil seed banks in plant invasions: promoting species invasiveness and long-term impact on plant community dynamics. Preslia, vol. 84 , pp. 327-350.

GIORIA, M., JAROŠÍK, V. and PYŠEK, P., 2014. Impact of invasions by alien plants on soil seed bank communities: emerging patterns. Perspectives in Plant Ecology, Evolution and Systematics, vol. 16, no. 3, pp. 132-142. http://dx.doi.org/10.1016/j. ppees.2014.03.003.

GOTTSBERGER, G. and SILBERBAUER-GOTTSBERGER, I., 2006. Origin, structure, dynamics and plant use. Ulm: Reta Verlag.

GRIME, J.P. 2001. Plant strategies, vegetation processes, and ecosystems properties. Chichester: John Wiley.

HARTIG, K. and BECK, E., 2003. The bracken fern (Pteridium arachnoideum (Kaulf.) (Maxon) in the Andes of Southern Ecuador, Ecotropica, vol. 9, pp. 3-13.

HERRERA, I. and NASSAR, J.M., 2009. Reproductive and recruitment traits as indicators of the invasive potential of Kalanchoe daigremontiana (Crassulaceae) and Stapelia gigantea (Apocynaceae) in a Neotropical arid zone. Journal of Arid Environments, vol. 73, no. 11, pp. 978-986. http://dx.doi. org/10.1016/j.jaridenv.2009.05.004.

HOFFMANN, W.A., 1998. Post-burn reproduction of woody plants in a neotropical savanna: the relative importance of sexual and vegetative reproduction. Journal of Applied Ecology, vol. 35, no. 3, pp. 422-433. http://dx.doi.org/10.1046/j.1365-2664.1998.00321.x.

HOFFMANN, W.A. and HARIDASAN, M., 2008. The invasive grass, Melinis minutiflora, inhibits tree regeneration in a Neotropical savanna. Austral Ecology, vol. 33, no. 1, pp. 29-36. http://dx.doi. org/10.1111/j.1442-9993.2007.01787.x.

KRONKA, F.J.N., NALON, M.A., MATSUKAMA, C.K., PAVÃO, M., GUILLAUMON, J.R., CAVALLI, A.C., GIANNOTTI, E., IWANE, M.S.S., LIMA, L.M.P.R., MONTES, J., DEL CALI, I.H., and HAACK, P.G., 1998. Áreas de domínio do cerrado no Estado de São Paulo. São Paulo: Secretaria de Estado do Meio Ambiente.

LORANDI, R., 1985. Caracterização dos solos das áreas urbana e suburbana de São Carlos (SP) e suas aplicações. Piracicaba: University of São Paulo.

MANHÃES, M.A., 2003. Dieta de Traupíneos (Passeriformes, Emberizidae) no Parque Estadual do Ibitipoca, Minas Gerais, Brasil. Iheringia: Série Zoologia, vol. 93, pp. 59-73.

MARCHANTE, H., FREITAS, H. and HOFFMANN, J.H., 2011. The potential role of seed banks in the recovery of dune ecosystems after removal of invasive plant species. Applied Vegetation Science, vol. 14, no. 1, pp. 107-119. http://dx.doi. org/10.1111/j.1654-109X.2010.01099.x.

MARRS, R.H. and WATT, A.S., 2006. Biological Flora of the British Isles: Pteridium aquilinum (L.) Kuhn. Journal of Ecology, vol. 94, no. 6, pp. 1272-1321. http://dx.doi.org/10.1111/j.13652745.2006.01177.x

MIATTO, R.C., SILVA, I.A., SILVA-MATOS, D.M. and MARRS, R.H., 2011. Woody vegetation structure of Brazilian Cerrado invaded by Pteridium arachnoideum (Kaulf.) Maxon (Dennstaedtiaceae). Flora - Morphology, Distribution. Functional Ecology of Plants, vol. 206, no. 8, pp. 757-762. http://dx.doi. org/10.1016/j.flora.2010.12.001.

MITCHELL, R.J., MARRS, R.H. and AULD, M.H.D., 1998. A comparative study of the seedbanks of heathland and successional habitats in Dorset, Southern England. Journal of Ecology, vol. 86 , no. 4, pp. 588-596. http://dx.doi.org/10.1046/j.13652745.1998.00281.x.

MYERS, N., MITTERMEIER, R.A., MITTERMEIER, C.G., DA FONSECA, G.A.B. and KENT, J., 2000. Biodiversity hotspots for conservation priorities. Nature, vol. 403, no. 6772, pp. 853-858. http://dx.doi.org/10.1038/35002501. PMid:10706275.

PAKEMAN, R.J. and HAY, E., 1996. Heathland Seedbanks under Bracken Pteridium aquilinum(L.) Kuhn and their Importance for Re-vegetation after Bracken Control. Journal of Environmental Management, vol. 47, no. 4, pp. 329-339. http://dx.doi.org/10.1006/ jema.1996.0057.

PINHEIRO, F., and RIBEIRO, J.F., 2001. Síndromes de dispersão de sementes em matas galeria do Distrito Federal. In J.F. RIBEIRO, C.E.L. FONSECA and J.C. SOUSA-SILVA. Cerrado: caracterização e recuperação de matas de galeria. Planaltina: Embrapa-Cerrados, pp. 335-375.

PINHEIRO, J.C., and BATES, D.M., 2000. Mixed-effects models in $S$ and $S$-PLUS. Springer.

PIVELLO, V.N.R., SHIDA, C.U.N. and MEIRELLES, S.T., 1999. Alien grasses in Brazilian savannas: a threat to the biodiversity. Biodiversity and Conservation, vol. 8, no. 9, pp. 1281-1294. http://dx.doi.org/10.1023/A:1008933305857.

PORTELA, R.C.Q., MATOS, D.M.S., SIQUEIRA, L.P.D., BRAZ, M.I.G., SILVA-LIMA, L. and MARRS, R.H., 2009a. Variation in aboveground biomass and necromass of two invasive species in the Atlantic rainforest, southeast Brazil. Acta Botanica Brasílica, vol. 23, no. 2, pp. 571-577. http://dx.doi.org/10.1590/ S0102-33062009000200029.

PORTELA, R.C.S.Q., MATOS, D.M.S., SIQUEIRA, L.P.D., BRAZ, M.I.G., SILVA-LIMA, L. and MARRS, R.H., 2009b. Variation in aboveground biomass and necromass of two invasive species in the Atlantic rainforest, southeast Brazil. Acta Botanica Brasílica, vol. 23, no. 2, pp. 571-577. http://dx.doi.org/10.1590/ S0102-33062009000200029.

R DEVELOPMENT CORE TEAM, 2014. R: a language and environment for statistical computing. Vienna: R Foundation for Statistical Computing.

ROBERTS, H.A., 1981. Seed banks in soils. Advances in Applied Biology, vol. 6, pp. 1-55.

SILVA MATOS, D.M. and SANTOS, C.J.F., 2002. Fire and restoration of the largest urban forest of the world in Rio de Janeiro City, Brazil. Urban Ecosystems, vol. 6, no. 3, pp. 151-161. http:// dx.doi.org/10.1023/A:1026164427792.

SILVA, Ú. and SILVA MATOS, D., 2006. The invasion of Pteridium aquilinum and the impoverishment of the seed bank in fire prone areas of Brazilian Atlantic Forest. Biodiversity and Conservation, vol. 15, no. 9, pp. 3035-3043. http://dx.doi. org/10.1007/s10531-005-4877-z. 
SILVA-MATOS, D.M., FONSECA, G.D.F.M., and SILVA-LIMA, L., 2005. Differences on post-fire regeneration of the pioneer trees Cecropia glazioui and Trema micrantha in a lowland Brazilian Atlantic Forest. Revista de Biología Tropical, vol. 53, pp. 1-4.

SILVEIRA, F.A.O., RIBEIRO, R.C., OLIVEIRA, D.M.T., FERNANDES, G.W. and LEMOS-FILHO, J.P., 2012. Evolution of physiological dormancy multiple times in Melastomataceae from Neotropical montane vegetation. Seed Science Research, vol. 22, no. 01, pp. 37-44. http://dx.doi.org/10.1017/S0960258511000286.

SIMPSON, R.L., 1989. Seed banks: general concepts and methodological issues. In M.A. LECK, V.T. PARKER and R.L. SIMPSON. Ecology of soil seed banks. San Diego: Academic Press.

THOMPSON, K. and GRIME, J.P., 1979. Seasonal variation in the seed banks of herbaceous species in ten contrasting habitats. Journal of Ecology, vol. 67, no. 3, pp. 893-921. http://dx.doi. org/10.2307/2259220.

THOMPSON, K., BAKKER, J.P., BEKKER, R.M. and HODGSON, J.G., 1998. Ecological correlates of seed persistence in soil in the north-west European flora. Journal of Ecology, vol. 86, no. 1, pp. 163-169. http://dx.doi.org/10.1046/j.1365-2745.1998.00240.x.
VAN DER VALK, A.G. and PEDERSON, L.P., 1989. Seed banks and the management and restoration of natural vegetation. In M.A. LECK, V.T. PARKER and R.L. SIMPSON. Ecology of soil seed banks. San Diego: Academic Press, pp. 329-344.

VAZQUEZ-YANES, C. and OROZCO-SEGOVIA, A., 1993. Patterns of seed longevity and germination in the tropical rainforest. Annual Review of Ecology and Systematics, vol. 24, no. 1, pp. 69-87. http://dx.doi.org/10.1146/annurev.es.24.110193.000441.

WEARNE, L.J. and MORGAN, J.W., 2006. Shrub invasion into subalpine vegetation: implications for restoration of the native ecosystem. Plant Ecology, vol. 183, no. 2, pp. 361-376. http:// dx.doi.org/10.1007/s11258-005-9046-7.

WILLIAMS, D. and BARUCH, Z., 2000. African grass invasion in the Americas: ecosystem consequences and the role of ecophysiology. Biological Invasions, vol. 2, no. 2, pp. 123-140. http://dx.doi.org/10.1023/A:1010040524588.

ZUUR, A., IENO, E.N., WALKER, N., SAVELIEV, A.A., and SMITH, G.M., 2009. Mixed effects models and extensions in ecology with R. Berlin: Springer.. http://dx.doi.org/10.1007/9780-387-87458-6. 